\title{
EVALUATION OF HYPERMETHYLATION OF RAS ASSOCIATION DOMAIN FAMILY-1 A AND GLUTATHIONE S-TRANSFERASE PROTEIN-1 GENES AS DIAGNOSTIC MARKER FOR HEPATOCELLULAR CARCINOMA
}

\author{
Prof. Dr. Karima Mohamad El-Sabakawy, Prof. Dr. Raymonde Hanna Assaf \\ Prof. Dr. Lamiaa Farouk Arafa, Dr. Osama Abd-Elgawad Shiha \\ Shymaa Mohsen Abd-elhamid El-Beeh \\ Medical Biochemistry - Faculty of Medicine - Mansoura University,Egypt
}

\begin{abstract}
Background and study aims: The molecular pathogenesis of HCC involves well-defined genetic and epigenetic alterations. The Ras association domain family $1 \mathrm{~A}$ (RASSF1A) and the Glutathione S-transferase P 1 (GSTP1) genes are two tumour suppressor genes that are reported to be silenced by $\mathrm{CpG}$ island promoter hypermethylation which is a key to the tumourigenic process in HCC. The aim of this study was to analyze the methylation frequency of RASSF 1A and GSTP1 genes in early stages of HCC, chronic hepatitis C and healthy subjects to evaluate its value as a diagnostic marker for early HCC. Patients and methods: Methylation-specific polymerase chain reaction (MSP) was used to detect RASSF1A and GSTP1 promotor methylation in DNA extracted from plasma samples of 25 patients with HCC, 25 patients with chronic hepatitis C and 25 healthy controls. Assessment of alpha fetoprotein (AFP) was performed in all groups by ELISA using commercially available kits. Results: Methylated RASSF1A was detected in $76 \%$ of the HCC group (19/25), in $20 \%$ of the chronic hepatitis C patients $(5 / 25)$ and in $16 \%$ of the healthy controls(4/25). The methylation frequencies were significantly higher in patients with HCC compared to the controls ( $\mathrm{P}$ $\leq 0.001)$ and chronic hepatitis $\mathrm{C}$ patients $(\mathrm{P} \leq 0.001)$. While methylated GSTP1 was detected in $44 \%$ of the HCC group $(11 / 25)$,in $12 \%$ of the chronic hepatitis $C$ group (3/25) and in $8 \%$ of the controls (2/25). Although the sensitivity and specificity, for each gene as an epigenetic biomarker was moderate (76\% and $44 \%$ for RASSF1A and GSTP1 respectively), the combination analysis of both genes resulted in an increased sensitivity and specificity to $88 \%$, and 76\% respectively) in discriminating HCC from normal control and chronic hepatitis C pateints. As regard AFP, Receiver operating characteristic curves were plotted and showed an optimal cutoff value of $9.5 \mathrm{ng} / \mathrm{ml}$ with sensitivity of $88 \%$ and specificity of $58 \%$ when the area under the receiver operator characteristic (AUROC) curve was 0.87 with $95 \%$ Confidence Interval .Conclusion: The epigenetic changes observed in this study indicate that examination of methylation status of RASSF1A and GSTP1 could be of value for early diagnosis of HCC especially when using a combination of more than one epigenetic marker .
\end{abstract}

\section{INTRODUCTION}

H epatocellular carcinoma (HCC) is the fifth most common and the third most fatal malignancy worldwide (1). While the incidence of many cancers is declining, HCC incidence continues on the upward trajectory over the last three decades in many countries. Over $80 \%$ of hepatocellular carcinoma cases are attributable to four major causes: infection with hepatitis $\mathrm{C}$ (HCV) or B (HBV) viruses, chronic alcohol consumption, and/or exposure to aflatoxin B1 (2). It is widely believed that the continuous epidemic of HCV largely accounts for the observed increase in HCC incidence(3). It has been stated that Egypt has the highest prevalence of hepatitis $\mathrm{C}$ worldwide and the epidemic will soon peak (4).

Although the prognosis of patients with HCC has marginally improved over the last few decades, the 5-year survival rate remains poor as a result of late diagnosis. The majority of patients with advanced HCC do not survive for longer than 6 months from the time of diagnosis $(5)$. Late presentation remains an important obstacle to successful treatment (6). Thus, early diagnosis of HCC represents the best opportunity for reduction of the worldwide burden of this disease on the human population (7). In this regard, biomarkers have been developed for early HCC detection ( 8 ).

Alpha-Fetoprotein (AFP) has been a classic blood tumor marker in HCCs for a long period, but both false-positive and false-negative results occur; markers with high sensitivity and specificity should be developed (9).

It is well known that many types of tumours shed cells and cellular material (including DNA) into the blood. Therefore, several strategies have been used for the detection of occult cancers using DNA from blood (10).

The molecular pathogenesis of HCC involves well-defined genetic and epigenetic alterations (2).A few number of genetic lesions have been identified in the molecular mechanisms of hepatocarcinogenesis such as $p 53$ and $R b$ alterations. Hypermethylation of Glutathione Stransferase p1 gene (GSTP1), which codes for as an enzyme that plays roles in detoxication and carcinogenesis; and Ras association domain family 1 A (RASSF1A) gene which blocks cell cycle, have been proved in HCC (11). The inactivation of RASSFIA and GSTPI promoters by methylation was detected in the plasma DNA as well as in the tissue DNA of HCC patients (12). 
The aim of this study was to analyze the methylation frequency of RASSFIA and GSTP1 genes in plasma DNA in early stages of HCC, chronic hepatitis $\mathrm{C}$ liver disease and healthy subjects to evaluate its value as a diagnostic marker for early HCC.

\section{MATERIALS AND METHODS}

\section{Patients and Control Subjects.}

This study included a total of 75 plasma samples. Twenty five of them were obtained from patients with early stages of hepatocellular carcinoma (nineteen males and six females with mean age $54.7 \pm 6.8$ years). Twenty five from chronic hepatitis $\mathrm{C}$ virus pateints (thirteen males and twelve females with mean age $(51.3 \pm 8.2)$. Twenty five age and sex matched healthy volunteers were included as control group (Seventeen males and eight females with mean age $44.2 \pm 1.1$ years). The patients were selected from outpatient clinics of Mansoura University Hospitals between September 2013 and October 2014.

Diagnosis of cases of HCC was based on the revised version of the Barcelona-Clinic Liver Cancer (BCLC) system, released by the American Association for the Society of Liver Diseases (AASLD) (13).

A total of $5 \mathrm{ml}$ blood samples were collected in both EDTA tubes (for plasma) and EDTA-free tubes (for serum).The plasma samples were centrifuged at $2000 \mathrm{rpm}$ (5 minutes), and plasma was carefully transferred into $2 \mathrm{ml}$ microtubes. Samples were centrifuged in a microcentrifuge at $5070 \mathrm{rpm}$ (10 minutes). All samples were processed within two hours after collection. Centrifugation steps were performed at $4{ }^{\circ} \mathrm{C}$ and supernatants were stored at $-80^{\circ} \mathrm{C}$ until analysis was performed.
The sera tubes were coagulated during approximately $1 \mathrm{~h}$, after which the serum were separated and stored for Estimation of the level of the hepatic tumour marker AFP : by ELISA. DNA Extraction from Plasma Samples.

Circulating cell free DNA was isolated from 1 $\mathrm{ml}$ plasma using QIAamp MinElute Virus Spin Kit (QIAGEN Catalog no. 57704) according to Sambrook and Russell, (14) and eluted in $50 \mu \mathrm{L}$ sterile water following the manufacturers' protocol. The concentration of isolated DNA was determined spectrophotometrically using NanoPhotometer® P-Class (Implen, Germany) according to Sambrook et al., (15).

\section{Bisulfite Conversion of DNA.}

Bisulfite modification and MSP were conducted based on the principle that bisulfite treatment of DNA converts unmethylated cytosine residues into uracil, whereas methylated cytosine residues would remain unmodified (16). Thus, after bisulfite conversion, methylated and unmethylated DNA sequences would be distinguishable by sequence-specific primers. Bisulfite treatment was conducted using the EpiTect Bisulfite Kit (QIAGEN Catalog no. 59104) (17).

Methylation-specific PCR (MSP):

MSP reaction was performed according to method by (16) using The EpiTect MSP Kit (2X) provided by QIAGEN, (cat No. 59305).

Bisulfite-modified DNA was amplified using primers specific for the methylated RASSFIA or GSTP1 sequence. Gene-specific primers were purchased from Oligo, Macrogen. Primer sets for the PCR amplification genes were selected based on published sequences (table 1). 
Table 1: Sequence of all primers used in the experiment .

\begin{tabular}{|c|c|c|c|c|}
\hline Gene & Primer sequence $\left(5^{\prime}-3^{\prime}\right)$ & $\begin{array}{l}\text { Product size } \\
\text { (bp) }\end{array}$ & $\begin{array}{l}\text { Anneal-ing } \\
\text { temp. }\left({ }^{\circ} \mathrm{C}\right)\end{array}$ & $\begin{array}{c}\text { Reference } \\
\text { s }\end{array}$ \\
\hline $\begin{array}{l}\text { RASSF1A } \\
\text { Methylated }\end{array}$ & $\begin{array}{l}\text { F: 5'- } \\
\text { GTGTTAACGCGTTGCGTTGCGT } \\
\text { ATC- 3' } \\
\text { R: 5'- } \\
\text { ACCCCGCGAACTAAAAACGA- } \\
\text { 3' }\end{array}$ & 93 & 60 & $\overline{(18)}$ \\
\hline $\begin{array}{l}\text { RASSF1A } \\
\text { Unmethylated }\end{array}$ & $\begin{array}{l}\text { F: 5'- } \\
\text { TTTGGTTGGAGTGTGTTAATGT } \\
\text { G- 3' } \\
\text { R: 5'- } \\
\text { CAAACCCCACAAACTAAAAAC } \\
\text { AA- 3' } \\
\end{array}$ & 105 & 60 & (18) \\
\hline $\begin{array}{l}\text { GSTP1 } \\
\text { Methylated }\end{array}$ & $\begin{array}{l}\text { F: 5'- } \\
\text { TTCGGGGTGTAGCGGTCGTC- 3' } \\
\text { R: 5'- } \\
\text { GCCCCAATACTAAATCACGACG } \\
-3^{\prime}\end{array}$ & 91 & 59 & (19) \\
\hline $\begin{array}{l}\text { GSTP1 } \\
\text { Unmethylated }\end{array}$ & $\begin{array}{l}\text { F: 5'- } \\
\text { GATGTTTGGGGTGTAGTGGTTG } \\
\text { TT- 3' } \\
\text { R: 5'- } \\
\text { CCACCCCAATACTAAATCACAA } \\
\text { CA- 3' }\end{array}$ & 97 & 59 & (19) \\
\hline
\end{tabular}

Control reactions were performed to ensure that the PCR primers are specific for the detection of methylated or unmethylated DNA. EpiTect Control DNA (Methylated and bisulfite converted human control DNA) from QIAGEN (cat.no 59655) was used as positive control. Genomic DNA extracted from blood lymphocytes was used as negative control.

The thermal cycler (Minicycler PTC- 150) was previously programmed according to cycling conditions outlined below: Initial activation step: 10 minutes at $95^{\circ} \mathrm{C}, 3$-step cycling (50 cycles): (Denaturation: 1 minute at $94^{\circ} \mathrm{C}$, Annealing: 30seconds at $60^{\circ} \mathrm{C}$, and Extension: 1 minute at $72{ }^{\circ} \mathrm{C}$ ) and Final extension: 10 minute at $72^{\circ} \mathrm{C}$.

Agarose Gel Electrophoresis of the MSP Products: (20).

PCR products were loaded into 3\% agarose gels and stained with ethidium bromide. Samples were scored as methylated when there was a clearly visible band on the gel with the methylated primers. Methylated RASSF1A produced a single 93 bp product, while Unmethylated RASSF1A produced a single 105 bp product.
Methylated GSTP1 produced a single $91 \mathrm{bp}$ product, while Unmethylated GSTP1 produced a single 97 bp product.

Statistical Analyses.

For Descriptive statistics : mean (M), and standard deviation (SD) were calculated. The difference of DNA methylation status between different groups was analyzed using chi-square or Fisher Exact tests. For calculation of sensitivity and specificity of AFP, the Receiver operating characteristic curves were plotted and optimal cutoff value was defined. Association between gene promoter methylation and AFP levels was determined using Mann-Whitney test. P values $<0.05$ were considered statistically significant.

\section{RESULTS}

Comparison of the RASSF1A gene methylation status in plasma DNA from hepatocellular carcinoma, chronic hepatitis $C$ patients and healthy controls :

The promoter methylation status of RASSF1A of DNA isolated from plasma was assayed by methylation-specific PCR(MSP)(figure1and 2). The methylation frequency of RASSF1A showed significant difference between the hepatocellular 
carcinoma group and both chronic hepatitis $\mathrm{C}$ group and the healthy controls $(\mathrm{P} \leq 0.001)$. There was no significant difference between chronic hepatitis $\mathrm{C}$ patients and healthy controls as regard methylation frequency $(\mathrm{P}=1)$, where in the 25 plasma samples from HCC cases, 19 (76\%) were positive for methylation of RASSF1A , Five (20\%) of the 25 chronic hepatitis $\mathrm{C}$ cases had methylation of RASSFIA, and four (16\%) of the 25 healthy controls (table 2 ).

Table 2: Methylation frequency for RASSF1A in HCC, chronic hepatitis $C$ patients and healthy controls.

\begin{tabular}{llllll}
\hline Gene & HCCs & $\begin{array}{c}\text { Chronic } \\
\text { patients } \\
(\mathrm{n}=25)\end{array}$ & $\begin{array}{c}\text { hepatitis } \\
(\mathrm{n}=25)\end{array}$ & $\begin{array}{c}\text { healthy } \\
\text { controls } \\
(\mathrm{n}=25)\end{array}$ & Test of significance \\
\hline $\begin{array}{c}\text { Methylated RASSF1A: } \\
\text { NO }(\%)\end{array}$ & $19(76)$ & $5(20)$ & $4(16)$ & $\begin{array}{c}\chi^{2}=24.1, \\
\mathrm{P} \leq 0.001\end{array}$ \\
\hline
\end{tabular}

Group comparison

HCC vs. CHC : $\chi^{2}=15.7, \mathrm{P} \leq 0.001$

HCC vs. healthy group $\chi^{2}=18.1, \mathrm{P} \leq 0.001$

Healthy group vs. CHC Fisher exact test $\mathrm{P}=1$

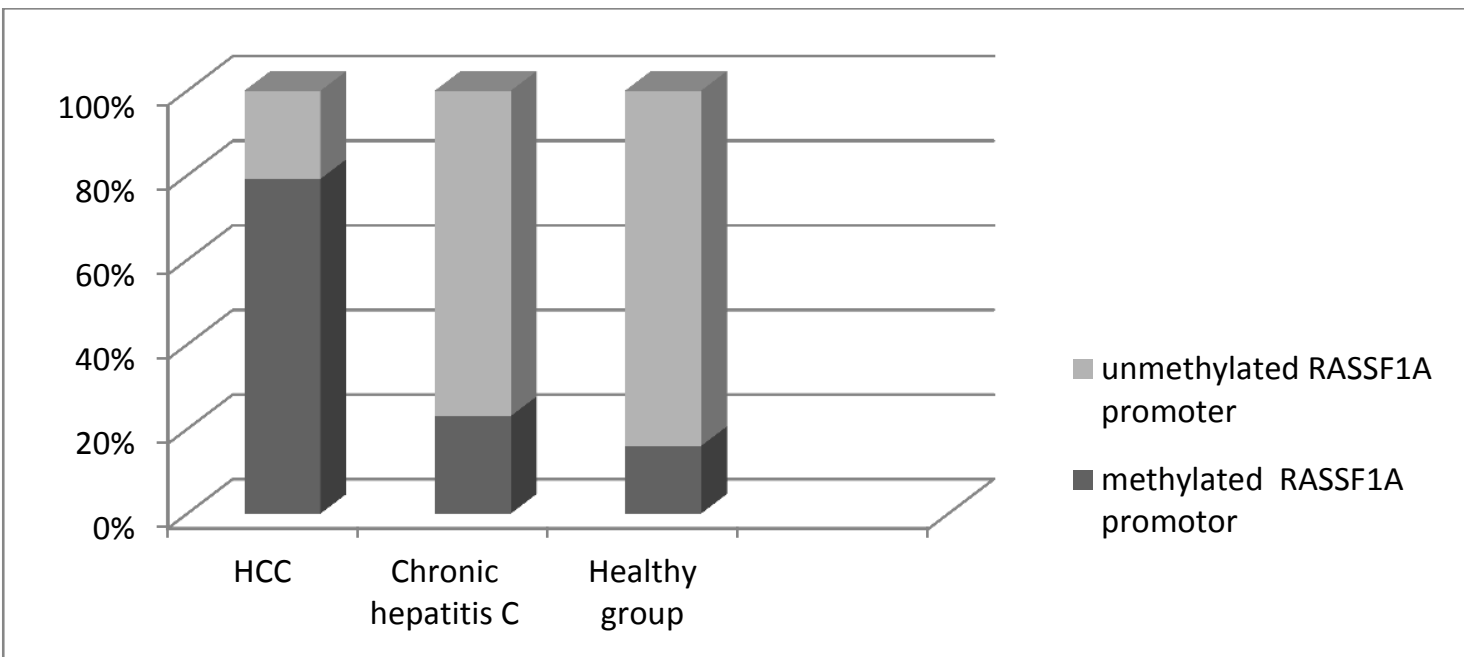

Figure (1): Representation of the promoter methylation status of RASSF1A in plasma DNA showing significant difference in methylation level between the hepatocellular carcinoma group and both chronic hepatitis $\mathrm{C}$ group and the healthy controls.

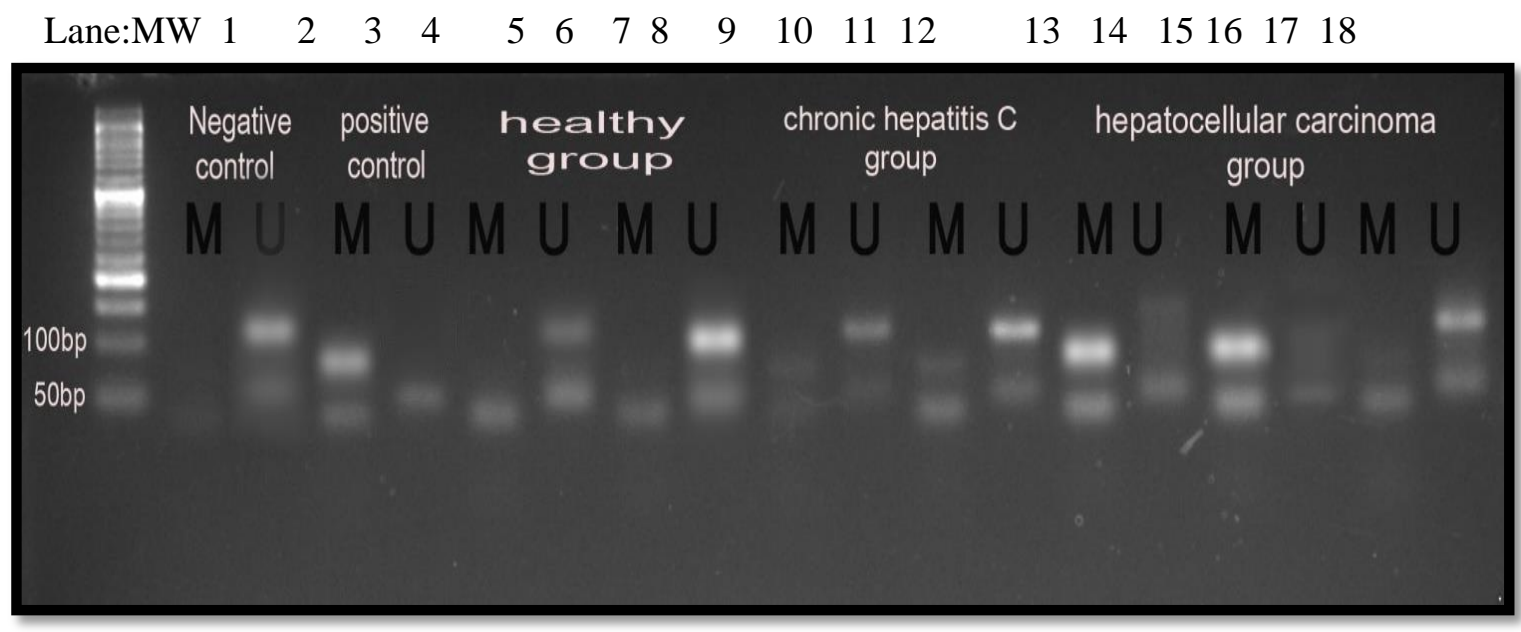

Figure (2): Gel electrophoresis showing methylation analysis of RASSF1A in plasma DNA.

MW: molecular weight marker $(50$ bp ladder).Lanes 1,2: Normal human lymphocytes
DNA used as negative control. Lanes 3,4: The Methylated and bisulfite converted human control 
DNA (from QIAGEN cat.no 59655) applied as a positive control. Lanes 5,6,7,8: Two cases of the healthy control group.Lanes 9,10,11,12: Two cases of the chronic hepatitis $\mathrm{C}$ group. Lanes 13,14,15,16,17,18: Three cases of the HCC group. (Lanes designated $\mathrm{M}$ : amplified products with RASSF1A -methylated primer 1; lanes designated $\mathrm{U}$, amplified products with RASSFIA unmethylated primer.

Comparison of the GSTP1 gene methylation status in plasma DNA from hepatocellular carcinoma, chronic hepatitis $C$ patients and healthy controls.

Aberrant methylation of the GSTP1 promoter region was detected in 11 out of 25 (44\%) plasma DNA samples from HCC patients. Three of the plasma samples from 25 chronic hepatitis $\mathrm{C}$ patients displayed GSTP1 promoter methylation (12\%), and two samples from 25 healthy controls displayed GSTP1 promoter methylation (8\%) (table 3) and (figure 3 and 4). The methylation frequency of GSTP1 showed significant difference between the hepatocellular carcinoma group and the healthy controls $(P=0.004)$ and the chronic hepatitis $\mathrm{C}$ group $(\mathrm{P}=0.01)$. There was no significant difference between chronic hepatitis $\mathrm{C}$ patients and healthy controls as regard methylation frequency $(\mathrm{P}=1)$.

Table 3 :Methylation frequency for GSTP1 in HCC, chronic hepatitis $C$ patients and healthy controls.

\begin{tabular}{|c|c|c|c|c|}
\hline Gene & $\begin{array}{l}\text { HCCs } \\
(n=25)\end{array}$ & $\begin{array}{lll}\text { Chronic } & \text { hepatitis } & \mathrm{C} \\
\text { patients } & & \\
(\mathrm{n}=25) & & \end{array}$ & $\begin{array}{l}\text { healthy } \\
\text { controls } \\
(\mathrm{n}=25)\end{array}$ & $\begin{array}{l}\text { Test of } \\
\text { significance }\end{array}$ \\
\hline $\begin{array}{l}\text { Methylated GSTP1: } \\
\text { NO }(\%)\end{array}$ & $11(44)$ & $3(12)$ & $2(8)$ & $\begin{array}{l}\chi^{2}=11.6 \\
P=0.003 *\end{array}$ \\
\hline Group comparison & \multicolumn{4}{|c|}{$\begin{array}{l}\text { HCC vs. } \mathrm{CHC}: \chi^{2}=6.4, \mathrm{P}=0.01 \mathrm{~s} \\
\mathrm{HCC} \text { vs. healthy group }: \chi^{2}=8.4, \mathrm{P}=0.004 \\
\text { Healthy group vs. } \mathrm{CHC}: \text { Fisher exact test } \mathrm{P}=1\end{array}$} \\
\hline
\end{tabular}

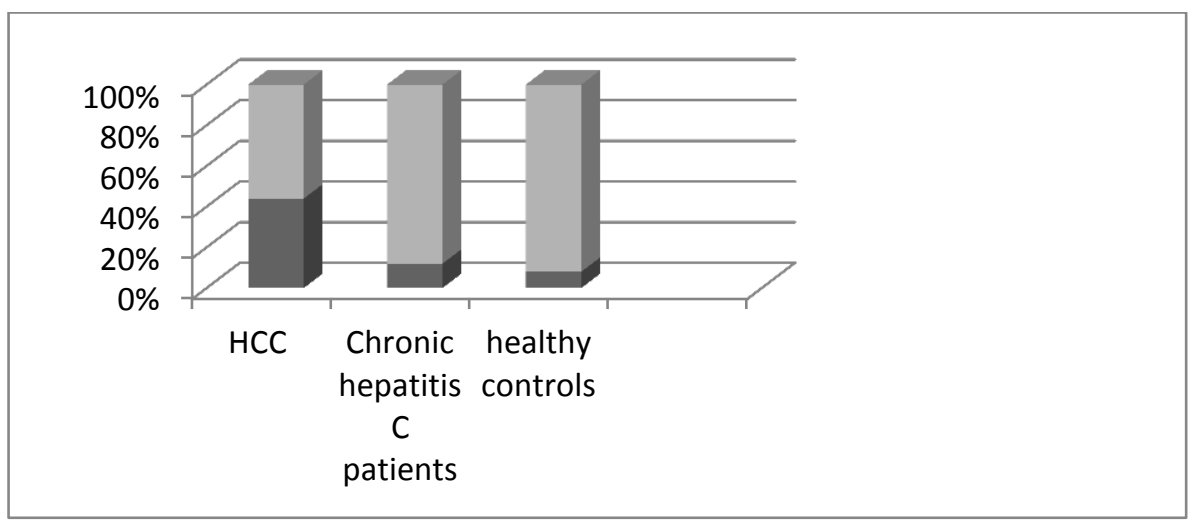

Figure (3): Representation of the promoter methylation status of GSTP1 in plasma DNA, showing significant difference in methylation level between the hepatocellular carcinoma group and both chronic hepatitis $\mathrm{C}$ group and the healthy controls. 


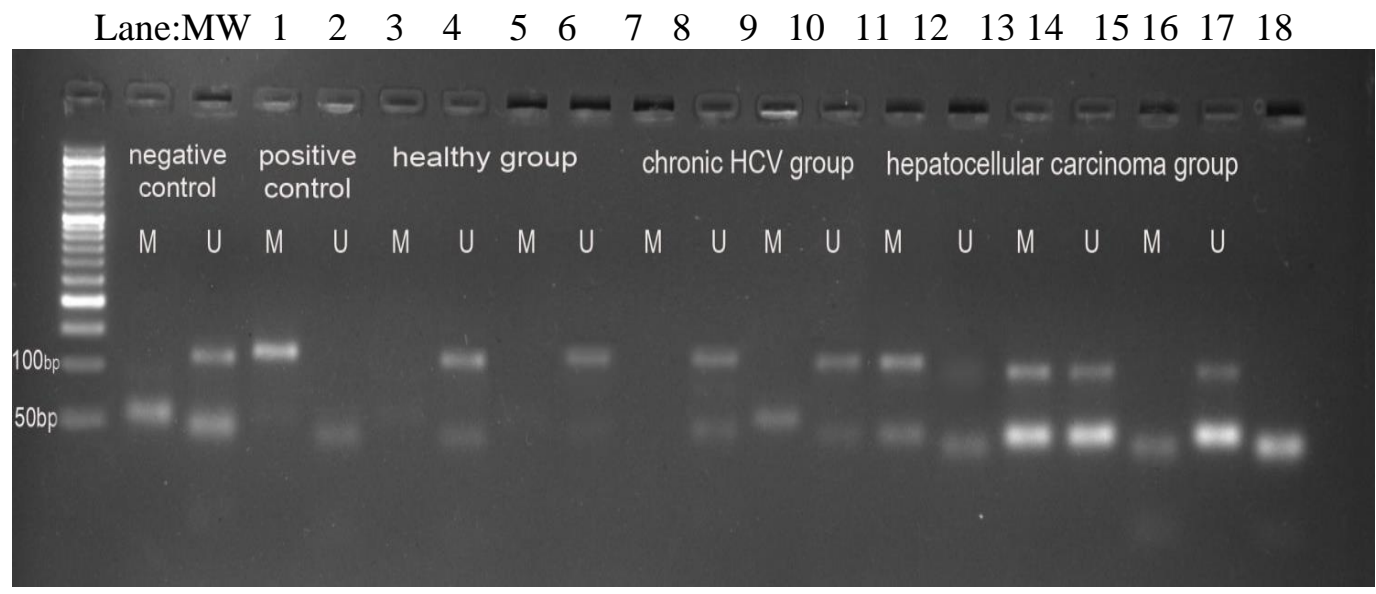

Figure (4): Gel electrophoresis showing methylation analysis of GSTP1 in plasma DNA .

MW: molecular weight marker $(50$ bp ladder).Lanes 1,2: Normal human lymphocytes DNA used as negative control. Lanes 3,4: The Methylated and bisulfite converted human control DNA (from QIAGEN cat.no 59655) applied as a positive control. Lanes 5,6,7,8: Two cases of the healthy control group. Lanes 9,10,11,12: Two cases of the chronic hepatitis $\mathrm{C}$ group. Lanes 13,14,15,16,17,18: Three cases of the HCC group. Lanes designated $\mathrm{M}$, amplified products with GSTP1 -methylated primer 1; lanes designated $\mathrm{U}$, amplified products with GSTPI unmethylated primer.

The diagnostic ability of RASSF1A, and GSTP1 genes methylation analysis :

Methylated RASSF1A was found to differentiate HCC patients from healthy controls with a sensitivity of $76 \%$, specificity of $84 \%$, The positive predictive value (PPV) was $83 \%$, and the negative predictive value ( NPV)
78\%. Methylated GSTP1 had a lower diagnostic ability in discriminating HCC from healthy controls with a sensitivity of $44 \%$, specificity 92\%, PPV $85 \%$, and NPV 62\% (table 4).

Methylated RASSFIA was also able to differentiate HCC from Chronic hepatitis C patients with a sensitivity of $76 \%$, specificity 80\%, PPV 79\%, and NPV 77\%. The sensitivity of methylated GSTP1 in discriminating HCC from Chronic hepatitis $\mathrm{C}$ patients was $44 \%$, specificity 88\%, PPV $79 \%$, and NPV 61\% ( table 4).

Combination analysis of the two genes for HCC detection among chronic hepatitis patients and healthy controls showed greater sensitivity (88\%) and comparable specificity (76\%) to each individual gene (76 \% -84\% and 44\%-92\%) (table 4)

Table 4: Diagnostic ability of plasma methylation analysis between HCC patients and healthy controls and between HCC patients and HCV group.

\begin{tabular}{|c|c|c|c|c|}
\hline & Sensitivity (\%) & Specificity (\%) & $\begin{array}{c}P P V \\
(\%) \\
\end{array}$ & $\begin{array}{l}N P V \\
(\%)\end{array}$ \\
\hline \multicolumn{5}{|c|}{ HCC patients vs. healthy controls. } \\
\hline RASSF1A & 76 & 84 & 83 & 78 \\
\hline GSTP1 & 44 & 92 & 85 & 62 \\
\hline $\begin{array}{c}\text { Analysis of both } \\
\text { genes }\end{array}$ & 88 & 76 & 79 & 86 \\
\hline \multicolumn{5}{|c|}{ HCC patients vs. HCV group. } \\
\hline RASSF1A & 76 & 80 & 79 & 77 \\
\hline GSTP1 & 44 & 88 & 79 & 61 \\
\hline $\begin{array}{c}\text { Analysis of both } \\
\text { genes }\end{array}$ & 88 & 76 & 82 & 87 \\
\hline
\end{tabular}


Median serum AFP level was $103 \mathrm{ng} / \mathrm{ml}$ in patients with $\mathrm{HCC}, 12 \mathrm{ng} / \mathrm{ml}$ in patients with chronic hepatitis $\mathrm{C}$, and $8 \mathrm{ng} / \mathrm{ml}$ in healthy controls. Receiver operating characteristic curves were plotted and showed an optimal cutoff value of $9.5 \mathrm{ng} / \mathrm{ml}$ with sensitivity of $88 \%$ and specificity of $58 \%$ when the area under the receiver operator characteristic (AUROC) curve was 0.87 with 95\% Confidence Interval (table 5 and figure 5).

Table 5 : Concentrations of AFP in HCC, chronic hepatitis C patients and healthy controls.

\begin{tabular}{|c|c|c|c|c|}
\hline & $\begin{array}{l}\text { HCC Group } \\
(n=25)\end{array}$ & $\begin{array}{l}\text { Chronic Virus C } \\
\text { Group } \\
(n=25)\end{array}$ & $\begin{array}{l}\text { Healthy Control } \\
\text { Group } \\
(n=25)\end{array}$ & $\begin{array}{l}\text { Test } \\
\text { significance }\end{array}$ \\
\hline $\begin{array}{l}\operatorname{AFP}(\mathrm{ng} / \mathrm{ml}) \\
\text { Median }(\min -\mathrm{max})\end{array}$ & $103(1.9-30400)$ & $12(5-32)$ & $8(2-12)$ & $\begin{array}{c}\text { Kruskal-Wallis } \\
\text { test } \\
\mathbf{P}<\mathbf{0 . 0 0 1}\end{array}$ \\
\hline Group comparison & \multicolumn{4}{|c|}{$\begin{array}{l}\text { HCC vs. CHC : Mann Whitney test } \mathbf{P}<\mathbf{0 . 0 0 1} \\
\text { HCC vs. healthy group : Mann Whitney test } \mathbf{P}<\mathbf{0 . 0 0 1} \\
\text { Healthy group vs. CHC : Mann Whitney test } \mathbf{P}<\mathbf{0 . 0 0 1}\end{array}$} \\
\hline
\end{tabular}

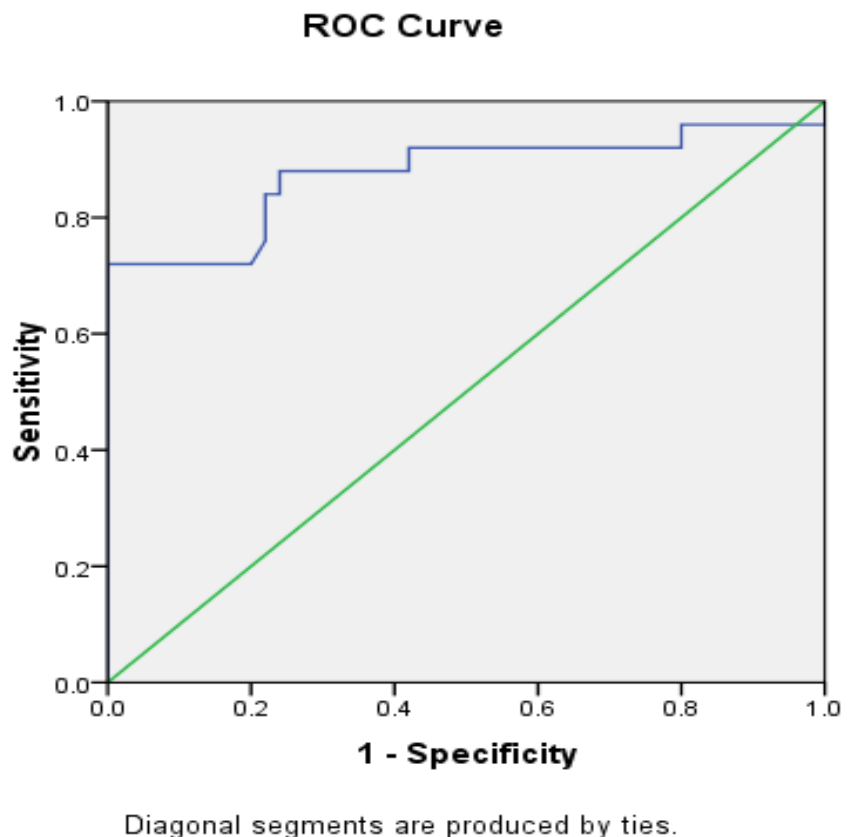

Figure (5) :ROC curves analysis of AFP

\section{Association between promoter methylation of RASSF1A and GSTP genes and AFP level:}

Although AFP level was higher in HCC cases with RASSF1A methylation than those with unmethylated promoters, the difference was not statistically significant $(\mathrm{P}=0.5)$. Regarding GSTP gene, HCC cases with unmethylated promoters had higher level of AFP, but also not statistically significant $(\mathrm{P}=0.9)$. As a conclusion, methylation of both tumour suppressor gene was not associated to AFP levels ( table 6). 
Table 6: Association between promoter methylation of RASSF1A, GSTP genes with AFP level.

\begin{tabular}{|c|c|c|c|}
\hline HCC group & $\begin{array}{l}\text { RASSF1A Methylated } \\
\text { Promoter }\end{array}$ & $\begin{array}{l}\text { RASSF1A } \\
\text { Unmethylated } \\
\text { promoter }\end{array}$ & $\begin{array}{c}\text { Test of significance } \\
(p \text {-value })\end{array}$ \\
\hline $\begin{array}{l}\text { AFP level } \\
\text { Median (min - max) }\end{array}$ & $139(1.9-7751)$ & $68.5(9-30400)$ & $\begin{array}{l}\text { Mann-Whitney test } \\
\mathrm{Z}=0.6 \\
\mathrm{P}=\mathbf{0 . 5}\end{array}$ \\
\hline & $\begin{array}{l}\text { GSTP } \\
\text { Methylated } \\
\text { Promoter }\end{array}$ & $\begin{array}{l}\text { GSTP Unmethylated } \\
\text { promoter }\end{array}$ & $\begin{array}{c}\text { Test of significance } \\
(p \text {-value })\end{array}$ \\
\hline $\begin{array}{l}\text { AFP } \\
\text { Median }(\min -\max )\end{array}$ & $85(2-30400)$ & $112.5(6.2-7751)$ & $\begin{array}{l}\text { Mann-Whitney test } \\
\mathrm{Z}=0.2 \\
\mathrm{P}=\mathbf{0 . 9}\end{array}$ \\
\hline
\end{tabular}

Estimation of AFP together with the examination of methylation status of RASSF1A and GSTP genes for HCC detection among chronic hepatitis patients has increased sensitivity to $96 \%$, with Specificity of $32 \%$, positive predictive value of $0.59 \%$ and negative predictive value of $89 \%$, and HCC detection among healthy subjects with sensitivity $96 \%$,
Specificity of $60 \%$, positive predictive value of $71 \%$ and negative predictive value of $94 \%$.

\section{Association between promoter} methylation and age for RASSF $1 A$ and GSTP genes:

There was no significant association between promoter methylation and age for any of the two genes in the three studied groups as shown in table (7) .

Table 7:Association between age and promoter methylation in HCC, chronic hepatitis C patients and healthy controls

\begin{tabular}{|c|c|c|c|c|}
\hline & & $\begin{array}{l}\text { Methylated promoter } \\
\text { (mean age } \pm S D)\end{array}$ & $\begin{array}{l}\text { Non-methylated promoter } \\
\text { (mean age } \pm S D)\end{array}$ & $\begin{array}{ll}\text { Test } & \text { of } \\
\text { significance } & (p- \\
\text { value })\end{array}$ \\
\hline \multirow[t]{2}{*}{ HCC group } & RASSFIA gene & $54.7 \pm 7.1$ & $54.7 \pm 6.2$ & $\mathrm{t}=0.02 \quad \mathrm{P}=1$ \\
\hline & GSTP gene & $57.1 \pm 8.8$ & $52.9 \pm 4.1$ & $\mathrm{P}=0.1$ \\
\hline \multirow[t]{2}{*}{ HCV group } & RASSFIA gene & $51.2 \pm 4.4$ & $51.3 \pm 9$ & $\mathrm{t}=0.02 \quad \mathrm{P}=1$ \\
\hline & GSTP gene & $48 \pm 0$ & $51.7 \pm 8.6$ & $\mathrm{t}=0.7 \quad \mathrm{P}=0.5$ \\
\hline \multirow{2}{*}{$\begin{array}{l}\text { Healthy } \\
\text { control } \\
\text { group }\end{array}$} & RASSFIA gene & $38.5 \pm 6.4$ & $45.3 \pm 10.9$ & $\mathrm{t}=1.2 \quad \mathrm{P}=0.2$ \\
\hline & GSTP gene & $55 \pm 0$ & $43.3 \pm 10.4$ & $\mathrm{t}=1.6 \quad \mathrm{P}=0.1$ \\
\hline
\end{tabular}

Association between promoter methylation and gender for RASSF1A and GSTP genes:

There was no significant association between promoter methylation and gender for any of the two genes ,except for RASSFIA gene promoter methylation and gender in the chronic hepatitis $\mathrm{C}$ group $(\mathrm{P}=0.04)$ where all cases with methylated promoters (5) were females (table 8). 
Table 8 :Association between gender and promoter methylation methylation in HCC, chronic hepatitis $C$ patients and healthy controls.

\begin{tabular}{|c|c|c|c|c|}
\hline & & $\begin{array}{l}\text { Methylated promoter } \\
\text { (mean age } \pm S D \text { ) }\end{array}$ & $\begin{array}{l}\text { Unmethylated promoter } \\
\text { (mean age } \pm S D)\end{array}$ & $\begin{array}{l}\text { Test of } \\
\text { significance } \\
\text { value })\end{array}$ \\
\hline $\begin{array}{l}\text { HCC } \\
\text { group }\end{array}$ & $\begin{array}{c}\text { RASSF1A gene } \\
\text { Male } \\
\text { Female }\end{array}$ & $\begin{array}{l}14(73.7) \\
5(83.3)\end{array}$ & $\begin{array}{l}5(26.3) \\
1(16.7)\end{array}$ & $P=1$ \\
\hline
\end{tabular}

\begin{tabular}{clll}
\hline GSTP gene & & & \\
Male & $9(47.4)$ & $10(52.6)$ & $\mathrm{P}=0.7$ \\
Female & $2(33.3)$ & $4(66.7)$ &
\end{tabular}

\begin{tabular}{|c|c|c|c|}
\hline $\begin{array}{l}\text { HCV } \\
\text { group }\end{array}$ & $\begin{array}{l}\text { RASSF1A gene } \\
\text { Male } \\
\quad \text { Female }\end{array}$ & $\begin{array}{l}0(0) \\
5(38.5)\end{array}$ & $\begin{array}{l}12(100) \\
8(61.5)\end{array}$ \\
\hline
\end{tabular}

\begin{tabular}{cl}
\hline GSTP gene & \\
Male & $0(0)$ \\
Female & $3(23.1)$
\end{tabular}

$12(100) \quad P=0.2$

\begin{tabular}{lclll}
\hline $\begin{array}{l}\text { Healthy } \\
\text { control } \\
\text { goup }\end{array}$ & $\begin{array}{c}\text { RASSFIA gene } \\
\text { Male }\end{array}$ & $0(0)$ & $7(100)$ & $\mathrm{P}=0.3$ \\
& Female & $4(22.2)$ & $14(77.8)$ & \\
& & & \\
& & & & \\
& GSTP gene & $0(0)$ & $7(100)$ & $\mathrm{P}=1$ \\
& Male & $16(88.9)$ & \\
\hline
\end{tabular}

\section{DISCUSSION}

While genetic alterations are proposed to contribute to the development and progression of HCC, the molecular mechanisms underlying this process remain unclear. Apart from $\mathrm{HBV}$ integration into the host genome (21), there is no consistent genetic change associated with hepatocarcinogenesis, and only a handful of genes (such as beta-catenin, axin, and p53) are known to be frequently mutated in HCC (22). This has led to research into alternative mechanisms by which major risk factor exposures promote hepatocarcinogenesis. Because epigenetic mechanisms are believed to be important in protection against viral genomes and in response to environmental factors (23), aberrant epigenetic changes associated with viral infection and exposure to environmental factors may trigger events that promote the neoplastic transformation of hepatocytes.
Aberrant DNA methylation is an epigenetic mechanism of gene silencing in a wide range of human cancers, including liver cancer (24). This epigenetic silencing, either alone or in combination with genetic changes, may lead to the inactivation of tumor suppressor genes and other cancer-associated genes promoting hepatocarcinogenesis. Several studies have identified aberrant $\mathrm{CpG}$ methylation of many genes in HCC . These studies provided a strong support for a critical role of epigenetic changes in the development and progression of HCC (25).

In this study, selection of relevant genes that could be valuable biomarkers for early detection of HCC was guided by three criteria: (1) genes that may have an association with liver cancer based on their supposed biological function, (2) genes that are newly identified as targets of methylation in cancer, and (3) genes that are proposed to be the frequent targets of hypermethylation in hepatocellular carcinoma. 
According to quantitative DNA methylation analysis studies by Lambert et al. (26), RASSF $1 A$ and GSTP1 genes exhibited a highly significant hypermethylation in HCC tumors compared to cirrhotic and normal liver tissues.

Most studies about DNA methylation focused on the analysis of tumor tissue. However, tumor tissue is not always available and not suitable for screening or early detection of HCC. In contrary, serum or plasma sample is easily obtained (27).

In the current study, the promoter methylation status of RASSF1A and GSTP1 genes were assayed in plasma rather than tissue according to many previous researches. Many studies have reported the concordance between the levels of methylated RASSF1A and GSTP1 genes in plasma and tissues. Chan et al. (12) reported that the predominant source of circulating methylated RASSF1A in HCC patients was likely to be the tumour cells, as they noticed a significant reduction in serum RASSF1A in the HCC patients after tumour resection. Yeo et al.,(28) found that RASSF1A promoter hypermethylation occurred at a high frequency in HCC and the aberrant methylation was also detectable in over $40 \%$ of matched plasma.

Similarly, Wang et al. (29) reported that the aberrant methylation of the GSTPl gene in the serum of patients was in agreement with tumor methylation status $(\mathrm{P}=0.004)$.

Chang et al. (9), however, failed to find agreement between plasma and tissue DNA. The study used RT-PCR to compare DNA methylation in plasma and tissue from eight HCC patients. The resulting lack of concordance might be attributable to the small sample size and plasma DNA degradation during RT-PCR.

In the present study, plasma was used for extraction of circulating DNA rather than serum because the percentage of tumor- origin DNA in circulating DNA is lower in serum circulating DNA versus plasma circulating DNA according to Lee et al. (30) and Taback et al.(31), since circulating DNA is derived from both tumor cells and non-tumor cells (32).

In the current study, using MSP, methylated RASSF $1 A$ was detected in $76 \%$ of the HCC group (19/25), in $20 \%$ of the chronic hepatitis C patients $(5 / 25)$ and in $16 \%$ of the healthy controls $(4 / 25)$.

Our results are in agreement with Yeo et al. (28) who detected RASSF1A methylation in DNA extracted from HCC tumors and paired plasma samples of 40 patients using MSP. Where aberrant methylation was detected in 17 (42.5\%) plasma from the $40 \mathrm{HCC}$ patients.
Zhang et al. (33) also detected methylation changes of RASSF1A by methylation-specific PCR in the serum of HCC patients And reported that the analysis of hypermethylaiton of RASSF1A, p16, and p15 in serum DNA is a valuable biomarkers for early detection of HCC .

Chan et al. (12) revealed that hypermethylated $R A S S F 1 A$ was found in the sera of $93 \%$ HCC patients, $58 \%$ HBV carriers, and $8 \%$ of normal volunteers. Mohamed et al. (34) found that methylated RASSFIA was detected in $10 \%$ of the controls $(2 / 20), 62.5 \%$ of the HCV group (25/40) and in $90 \%$ of the HCC group (36/40). Their positive ratios of RASSF1A was higher than ours .The different target $\mathrm{CpG}$ cites may be the major reason for the difference in detection ratio or it may be attributed to the difference in the technique used where we used methylation-specific PCR, while they used the combination of methylation-sensitive restrictionenzyme digestion and real-time PCR detection.

Moribe et al. (35) suggested that RASSF1A showed the best performance for the discrimination of $\mathrm{HCC}$ and non-HCC liver tissues. They added that a combination of RASSF1A, CCND2 and SPINT2 showed 89-95\% sensitivity, 91-100\% specificity and $89-97 \%$ accuracy in discriminating between HCC and nonHCC tissues. Saelee et al. (36)demonstrated a significant correlation between the methylation status of RASSF 1A and HCC patients who did not undergo chemotherapy. Their findings showed that RASSF1A-promoter hypermethylation may serve as a good prognostic factor. In addition to the study of Lambert et al. (2011) who found a high frequency of aberrant hypermethylation of RASSF1A in HCC tumours as compared to normal liver tissue.

The results of this study demonstrated that methylated GSTP1 was detected in $44 \%$ of the HCC group(11/25) ,in $12 \%$ of the chronic hepatitis C group (3/25) and in $8 \%$ of the controls $(2 / 25)$.Our results are consistent with the study of Wang et al., (29) where GSTP1 promoter hypermethylation was detected in 16 of $32(50 \%)$ of circulating tumor DNA in the peripheral serum from HCC patients. In addition, Anzola et al. (37) reported that hypermethylation was detected in $56.7 \%, 43.3 \%$ and $17.9 \%$ of the tumour tissues for p16INK4a, pI4ARF, and GSTP1 genes, respectively. Zhang et al. (38) reported that GSTP1 promoter hypermethylation was detected in 38 of $83(46 \%)$ hepatocellular carcinoma tissues using Methylation-specific PCR (MSP). Lambert et al. (26) reported a high frequency of aberrant hypermethylation of GSTPI in HCC 
tumours as compared to control cirrhotic or normal liver . Also, study by Lee et al. (11) managed to show that patients with high GSTP1 methylation level have worse overall survival outcome .

In the study by Hua et al. (39), the methylation level of a panel of nine tumour suppressor genes was evaluated using a restriction enzyme digestion-based qPCR method, MSREqPCR. They showed that the methylation levels or frequencies of a panel of six genes (APC, GSTP1, RASSF1A, CDKN2A, RUNX3 and SFRPI) were significantly higher in HCCs when compared to surrounding matched non- tumorous tissues, and the combination analysis of these methylated genes could discriminate HCC well from nontumorous tissues.

In another study by Huang et al. (27) using methylation-sensitive restriction enzymes-based quantitative PCR (MSRE-qPCR), The methylation status of four genes (APC, GSTPI, RASSF1A, and SFRPI) was evaluated in 150 plasma samples, including 72 patients with HCC, 37 with benign live diseases and 41 normal controls, and revealed that the Methylation percentages of these four genes were higher in HCCs than in benign controls or healthy controls $(\mathrm{P} \leq 0.05)$.

The low frequency of methylation status of GSTP1 in the plasma samples in our study ( $44 \%$ of HCC cases ) could be a result of DNA degradation during the step of bisulfite conversion or incomplete conversion of DNA in the sample.

The presence of aberrant methylation in RASSF1A and GSTP1 genes in plasma DNA from patients with chronic hepatitis $\mathrm{C}$, although at low frequency, (Five (20\%) of the 25 chronic hepatitis C cases had methylation of RASSF1A ,Three of the plasma samples from 25 chronic hepatitis C patients displayed GSTP1 promoter methylation (12\%) , may indicate early methylation changes in normal cells that precede their oncogenic transformation. Alternatively, it may reflect the presence of microscopically undetectable transformed hepatocytes. it is possible that proliferative stimuli associated with inflammation may induce higher levels of methylation, While the mechanism underlying the activation of the methylator pathway remains unclear and requires further investigation.

Regarding the healthy controls, our results showed methylation of RASSF1A in four $(16 \%)$ of the 25 healthy controls , while two samples displayed GSTP1 promoter methylation (8\%), which is close to the results of Zhang et al.( 33), who detected methylated RASSF1A in
$6 \%$ of control DNA samples. In concordance with Chan et al. (12) who reported the presence of methylated RASSF1A in $8 \%$ of the healthy volunteers using realtime PCR after digestion with a methylation-sensitive restriction enzyme. More recently, Mohamed et al. (34) detected methylated RASSF $1 A$ in $10 \%$ of the controls. In a study by Dumache et al.,(40), hypermethylation of the GSTP1 gene was detected in $10.6 \%$ of control plasma samples. The methylation of both genes in healthy group may be due to an underlying undetectable bilharzial liver fibrosis or cirrhosis.

As regard AFP, in the present study serum the median level was $103 \mathrm{ng} / \mathrm{ml}$ in the patients with $\mathrm{HCC}, 12 \mathrm{ng} / \mathrm{ml}$ in patients with chronic hepatitis $\mathrm{C}$, and $8 \mathrm{ng} / \mathrm{ml}$ in healthy controls . Receiver operating characteristic curves were plotted and showed an optimal cutoff value being $9.5 \mathrm{ng} / \mathrm{ml}$ with sensitivity of $88 \%$ and specificity of $58 \%$ when the area under the receiver operator characteristic (AUROC) curve was 0.87 with 95\% Confidence Interval. This is in accordance with Gad et al. (41) where AFP showed a sensitivity/specificity of $86 \%$ and $78 \%$ respectivelyat a cut off point of $10 \mathrm{ng} / \mathrm{mL}$. The study of Lok et al., (42) showed that the sensitivity and specificity of AFP was $61 \%$ and $81 \%$ at a cutoff of $20 \mathrm{ng} / \mathrm{mL}$ which is different from our results due to different cut off points.

Lack of association between methylation of both tumour suppressor gene and AFP levels can help diagnosis by Estimating both AFP with the examination of methylation status of RASSF1A and GSTP genes, which increases sensitivity up to $96 \%$, with Specificity of $32 \%$, positive predictive value of $0.59 \%$ and negative predictive value of $89 \%$ for HCC detection among chronic hepatitis patients, and with sensitivity $96 \%$, Specificity of $60 \%$, positive predictive value of $71 \%$ and negative predictive value of $94 \%$ for $\mathrm{HCC}$ detection among healthy subjects.

In conclusion, HCC patients had significantly higher frequency of methylated RASSFIA and GSTP1 compared to controls and patients with chronic hepatitis $\mathrm{C}$ in the DNA extracted from plasma using MSP. Examination of methylation status of these tumour suppressor genes, especially when using a combination of more than one epigenetic marker, could be of value for early diagnosis of HCC.

\section{REFERENCES}

1. Gomaa AI, Khan SA, Toledano MB, Waked I, Taylor-Robinson SD (2008) :Hepatocellular carcinoma: epidemiology, 
risk factors and pathogenesis. World $J$ Gastroenterol.; 14:4300-4308.

2. Thorgeirsson SS, and Grisham JW (2002): Molecular pathogenesis of human hepatocellular carcinoma. Nat Genet.; 31:339-346.

3. Umemura $\mathrm{T}$, Ichijo $\mathrm{T}$, Yoshizawa $\mathrm{K}$, Tanaka E, Kiyosawa K (2009): Epidemiology of hepatocellular carcinoma in Japan. $J$ Gastroenterol.; 44(Suppl):102-107.

4. Yahia M (2011): Global health: a uniquely Egyptian epidemic. Nature; 474(7350 Suppl.). S12-3.

5. Nagai H, Sumino Y (2008):Therapeutic strategy of advanced hepatocellular carcinoma by using combined intraarterial chemotherapy. Recent Pat Anticancer Drug Discov. ;3(3):220-6.

6. Kung JWC, MacDougall M, Madhavan KK, et al., (2007): Predicting survival in patients with hepatocellular carcinoma: a UK perspective. Eur $J$ Surg Oncol;33(2):188-194.

7. Rivenbark AG, and Coleman WB (2007): The use of epigenetic biomarkers for preclinical detection of hepatocellular carcinoma: potential for noninvasive screening of high-risk populations. Clin Cancer Res;13(8):2309-2312.

8. Sherman M. (2005) : Diagnosis of small hepatocellular carcinoma. Hepatology ;42(1):14-6.

9. Chang H, Yi B, Li L, Zhang H, Sun F, Dong Sh , and Cao Y (2008): Methylation of tumor associated genes in tissue and plasma samples from liver disease patients. Experimental and Molecular Pathology ; 85 : 96-100.

10. Sidransky D (2002): Emerging molecular markers of cancer. Nat Rev Cancer ;2(3):210-219.

11. Lee S, Lee HJ, Kim JH, Lee HS, Jang JJ, and Kang GH (2003): Aberrant CpG island hypermethylation along multistep hepatocarcinogenesis. Am. J. Pathol. 163: 1371-1378.

12. Chan KCA, Lai PBS, Mok TSK, et al., (2008): Quantitative analysis of circulating methylated DNA as a biomarker for hepatocellular carcinoma. Clin Chem ;54(9):1528-36.

13. Bruix J, Sherman M (2011): AASLD Practice Guideline. Management of hepatocellular carcinoma: an update. Hepatology:;53(3):1020-1022.
14. Sambrook J and Russell DW (2001): Molecular Cloning: A Laboratory Manual, Cold Spring Harbor Laboratory Press, New York.

15. Sambrook J, Fritschi EF and Maniatis T (1989): Molecular cloning: a laboratory manual, Cold Spring Harbor Laboratory Press, New York.

16. Herman JG, Graff JR, Myohanen S, et al. (1996):Methylation-specific PCR: a novel PCR assay for methylation status of $\mathrm{CpG}$ islands. Proc Natl Acad Sci U S A 93 :9821- 9826.

17. Frommer M, McDonald LE, Millar DS, et al. (1992): A genomic sequencing protocol that yields a positive display of 5-methylcytosine residues in individual DNA strands. Proc Natl Acad Sci U S A;89: 1827-1831.

18. Lo KW, Kwong J, Hui $\mathrm{ABU}$, et al. (2001) :High frequency of promoter hypermethylation of RASSF1A in nasopharyngeal carcinoma. Cancer Res (61) :3877-3881.

19. Esteller M, Corn PG, Urena JM, et al. (1998): Inactivation of glutathione stransferase P1 gene by promoter hypermethylation in human neoplasia. Cancer Res 58 :4515-4518.

20. Boffy SA (1984): Agarose Gel Electrophoresis of DNA. In: Methods in Molecular Biology, Nucleic Acids, Walker, J.M. (Ed.). Homana Press, Clifton, New Jersey, pp: 43-50.

21. Paterlini-Brechot P, Saigo K, Murakami Y, Chami M, Gozuacik D, Mugnier C, et al., (2003): Hepatitis B virus-related insertional mutagenesis occurs frequently in human liver cancers and recurrently targets human telomerase gene. Oncogene; 22 (25):3911-3916.

22. Laurent-Puig $P$, and Zucman-Rossi $\mathrm{J}$ (2006): Genetics of hepatocellular tumors. Oncogene;25 (27):3778-3786.

23. Herceg Z (2007): Epigenetics and cancer: towards an evaluation of the impact of environmental and dietary factors. Mutagenesis ;22 (2):91-103.

24. Jones PA, and Baylin SB (2002): The fundamental role of epigenetic events in cancer. Nat Rev;3 (6):415-428.

25. Shen L, Ahuja N, Shen Y, Habib NA, Toyota M, Rashid A, et al.(2002): DNA methylation and environmental exposures in human hepatocellular carcinoma. J Natl Cancer Inst ;94 (10):755-761. 
26. Lambert MP, Paliwal A, Vaissière T, et al. (2011): Aberrant DNA methylation distinguishes hepatocellular carcinoma associated with $\mathrm{HBV}$ and $\mathrm{HCV}$ infection and alcohol intake. J Hepatol;54(4):705715 .

27. Huang $\mathrm{ZH}, \mathrm{Hu} \mathrm{Y}$, Hua D,Wu YY, Song MX, Cheng ZC (2011):Quantitative analysis of multiple methylated genes in plasma for the diagnosis and prognosis of hepatocellular carcinoma. Experimental and Molecular Pathology 91 : 702-707.

28. Yeo W, Wong $\mathrm{N}$, Wong $\mathrm{WL}$, et al. (2005): High frequency of promoter hypermethylation of RASSF1A in tumor and serum of patients with hepatocellular carcinoma. Liver Int; 25:266-272.

29. Wang J, Qin Y, Li B, Sun Z, Yang B (2006): Detection of aberrant promoter methylation of GSTP1 in the tumor and serum of Chinese human primary hepatocellular carcinoma patients. Clin Biochem.;39(4):344-348.

30. Lee TH, Montalvo L, Chrebtow V, Busch MP (2000):Quantitation of genomic DNA in plasma and serum samples: higher concentrations of genomic DNA found in serum than in plasma. Transfusion.41:276-282.

31. Taback B, O'Day SJ, Boasberg PD, et al. (2004): Circulating DNA microsatellites: molecular determinants of response to biochemotherapy in patients with metastatic melanoma. J Natl Cancer Inst. 96(2):152-156.

32. Van der Drift MA, Hol BE, Klaassen $\mathrm{CH}$, Prinsen CF, van Aarssen YA, Donders R, et al.(2010): Circulating DNA is a noninvasive prognostic factor for survival in non-small cell lung cancer. Lung Cancer. 68:283-287.

33. Zhang YJ, Wu HC, Shen J, et al.(2007) : Predicting hepatocellular carcinoma by detection of aberrant promoter methylation in serum DNA. Clin Cancer Res 2007;13(8):2378-84.

34. Mohamed NA, Swify EM, Amin NF, Soliman MM, Tag-Eldin LM and, Elsherbiny NM(2012): Is serum level of methylated RASSF1A valuable in diagnosing hepatocellular carcinoma in patients with chronic viral hepatitis C? Arab Journal of Gastroenterology; 13 : $111-115$
35. Moribe T, lizuka N, Miura T, et al.(2009): Methylation of multiple genes as molecular markers for diagnosis of a small, well-differentiated hepatocellular carcinoma. Int J Cancer; 125(2):388-397.

36. Saelee $P$, Wongkham $S$, Chariyalertsak $S$, et al. (2010): RASSF1A promoter hypermethylation as a prognostic marker for hepatocellular carcinoma. Asian Pac $J$ Cancer Prev 11: 1677-1681.

37. Anzola M, Cuevas N, López-Martínez M, Martínez de Pancorbo $\mathrm{M}$, and Burgos JJ(2004): Patterns of methylation profiles as diagnostic markers for multiple hepatocellular carcinomas. Gastroenterol:;39(3):246-251.

38. Zhang YJ, Chen Y, Ahsan H, Lunn RM, Chen SY, Lee PH, Chen CJ, and Santella RM (2005):Silencing of glutathione Stransferase $\mathrm{P} 1$ by promoter hypermethylation and its relationship to environmental chemical carcinogens in hepatocellular carcinoma. Cancer Lett.;221(2):135-143.

39. Hua D, Hu Y, Wu YY, Cheng ZH, Yu J, Du X, and Huang ZH (2011): Quantitative methylation analysis of multiple genes using methylation-sensitive restriction enzymes-based quantitative PCR for the detection of hepatocellular carcinoma. Experimental and Molecular Pathology 91: 455-460.

40. Dumache R, Puiu M, Motoc M, Vernic C, Dumitrascu V(2014):Prostate cancer molecular detection in plasma samples by glutathione S-transferase P1 (GSTP1) methylation analysis. Clin Lab.;60(5):847-852.

41. Gad A, Tanaka E, Matsumoto A, Wahab MA, Serwah Ael-H, Attia F, Ali K, Hassouba H, el-Deeb Ael-R, Ichijyo T, Umemura T, Muto H, and Yoshizawa K, Kiyosawa K(2005): Assessment of KL-6 as a tumor marker in patients with hepatocellular carcinoma. World $J$ Gastroenterol. ;11(42):6607-6612.

42. Lok, AS, Sterling RK, Everhart JE, Wright EC, Hoefs JC, Di Bisceglie A M, and Dienstag JL (2010):Des-gammacarboxy Prothrombin and Alpha fetoprotein as Biomarkers for the Early Detection of Hepatocellular Carcinoma. Gastroenterology, 138(2): 493 -502 